\title{
Potières et apprenties Vere du Cameroun. Styles techniques et processus d'apprentissage
}

\section{Hèlène Wallaert-Pêtre}

\section{(2) OpenEdition \\ 12 Journals}

Édition électronique

URL : https://journals.openedition.org/tc/353

DOI : $10.4000 /$ tc. 353

ISSN : 1952-420X

Éditeur

Éditions de l'EHESS

\section{Édition imprimée}

Date de publication : 1 juillet 1999

ISSN : 0248-6016

\section{Référence électronique}

Hèlène Wallaert-Pêtre, « Potières et apprenties Vere du Cameroun. Styles techniques et processus d'apprentissage », Techniques \& Culture [En ligne], 33| 1999, mis en ligne le 26 octobre 2005, consulté le 29 septembre 2022. URL : http://journals.openedition.org/tc/353 ; DOI : https://doi.org/10.4000/tc. 353

Ce document a été généré automatiquement le 29 septembre 2022.

Tous droits réservés 
Potières et apprenties Vere du Cameroun. Styles techniques et processus d'apprentissage

Hèlène Wallaert-Pêtre 